\title{
Empowerment of Women in Rural Odisha through Microenterprises
}

\author{
Sandhya Rani Mohanty ${ }^{1}$, Bijaylaxmi Das ${ }^{2}$ and Trupti Moahanty ${ }^{3}$ \\ ${ }^{1}$ Head of the Department of Home Science, Banki Autonomous College Banki, Cuttack, Odisha, India 754008 \\ ${ }^{2}$ Utkal University Bhubaneswar, Odisha, India, ${ }^{3}$ Orissa University of Agriculture and Technology, \\ Bhubaneswar, Odisha, India
}

\begin{abstract}
Organizing rural women through Self Help Groups and equip them to earn income by the formation of microenterprises have created an economic revolution in Odisha, India. Empowerment of women through microenterprises in rural Odisha can challenge their traditional practice and culture to effectively promote their well being. The present study addresses women empowerment through microenterprises in Cuttack district of Odisha. In this research work, field data were collected from rural women based on their working pattern, economic condition, family background, education level, and size of the family. Descriptive Statistics including frequencies, percentage, mean and standard deviations were carried out to draw meaningful interpretation of the results and to find out the reasons for joining the microenterprises. The result of the study revealed that microenterprises programmes have had greater impact on both social and economical aspects of the rural women in Odisha. The successful functioning of microenterprises provides economic independence to women leading to their empowerment.
\end{abstract}

Keywords: Women Empowerment, Microenterprises, Income generation, Rural Odisha.

\section{Introduction}

Microenterprise development contributes to widen the pool entrepreneurship available to society and it broadens the base of private sector. Looking at the poverty, unemployment, labour market scenario, the state Odisha of India could not be able to engage the existing unemployed workforces along with casual labourers who have no regular source of work or income. More ever, it is evident that Odisha is already facing almost stagnated employment growth in industrial sector and declined employed growth in agricultural sector. The service sector has increased its share of employment marginally but not adequate to employ the large percentage of unemployed and under employed. On the contrary, micro and small enterprises largely belonging to unorganised sector have created the bulk of employment in Odisha next to agriculture. The small-scale industries in Odisha, including tiny micro industries and service/business entities, collectively referred as Micro and Small enterprises (MSEs), have a long history of promoting inclusive, spatially indispensable and employment oriented growth in terms of employment generation. Realizing the potential of MSEs, not only Govt. of Odisha but also NGOs have come forward to strengthen Self Help Groups (SHGs) in relation with the microenterprises. MSEs are recognized as an important constituent of the state economics, contributing significantly to employment expansion and poverty alleviation. It is also clear that the share of the selfemployed workers in the Odisha workforces has increased tremendously of which a large percentage are economically poor. Therefore, it is pivotal to promote self-employment and microenterprise development to address the poverty, unemployment, and inclusive growth.

\section{REVIEW OF RESEARCH}

During the course of study, several references have been cited in this research article. Microenterprise refers to any economic unit engaged in the production and distribution of goods and services at household level. It is primarily self-employed in nature. The enterprise runs on little amount of capital investment at a fixed market centre or mobile business locations. This sector is identified with features like reliance on indigenous resources, family ownership of enterprises, small scale of operations, labour intensive \& adopted technologies, and minimum skill. Microenterprise, therefore, is particularly suitable for poor communities. Dhakal (2006) points out that microenterprise play a vital role in poverty reduction in both urban and rural areas and reinforce urbanrural linkages for social and economical development in Nepal. The linkages are essential not only for local resources but also in acting as agents for the flow of goods and services between rural and urban areas. Their roles are important since they facilitate self-employment generation through labour intensive traditional enterprise and craftsmanship, employment to poor and women, optimum use of local resources, meeting basic needs of the poor, self-satisfaction on the job, new entrepreneurship venture and equitable distribution of income among the poor. Most of the approaches explaining entrepreneurship and enterprise development start from 
economist's point of view (Bruni et.al; 2004) because entrepreneurs bring changes to economic development (Ab. Aziz et.al; 2005). The discipline of economy explains the entrepreneurship as a capacity of innovation (Ogber, 2009; Collin and More, 1964; Coli, 1959). Economists are different from capitalists who supply capital and manipulate other parties involved (Cautillon in Hisrich and peter; 1998). For this reason, entrepreneurship refers to the rural women who are running enterprise using their own ideas and develop their products. For the enterprise to succeed, the entrepreneurs should be continuously innovative. This is supported by Knight's theory of Risk (Knight; 1921, Schumpeterian theories Schumpeter; 1939 and Cole's theory of enterprise creation as cited in Bruni; 2004). For the success of the enterprise, innovativeness in entrepreneurs has to play a vital role. If they die, enterprise also dies and closes down (Dillinger, 1995). Most of the economic approaches mainly focus on macro issues of rural enterprise development, for an example, the role of micro business in rural economic growth, of which very few has been addressed but is of immense importance to empower the entrepreneur (rural women) in order to sustain the growth as well as scaling up enterprise. Gibbs (1972) called this entrepreneurship model as social development model, which explains that each process would go through to bring changes through business activities. Kantoor (2002) suggested developing a more holistic evaluation of micro enterprise success sensitive to the effects of power relations, an assessment of traditional economic outcomes must combine with measuring representing evidence of empowerment. In particular, the standard measures of economic outcomes should be assessed along with measures of women control over enterprise resources, particularly the income generated and involvement in decision making in typical spheres relevant to women in women culture of interest. These dimensions will illustrate how well women's involvement in selfemployment has translated into both economic success and control over their lives. The above literature review exposes the lacunae in the process of women empowerment and attempts to define the problem relevant to the present context.

\section{Statement Of The Problem}

Academicians, Intelligentsia, and policymakers have always shown their concern seriously about the issues related to women. The role of women has changed dramatically from stone age to contemporary global society. The process of Industrialization, modernisation and globalisation show its deep impact on human society all over the world. The role and responsibilities of women have attained new definition and perspective. On the encouraging side, in the state like Odisha, there has been a relatively increase in economic participation in the past one decade. Statistically, the rate of literacy among women has also increased. The educational and occupational patterns have also changed and widened with women entering the domains, which until decade back was considered to be dominated by men. The women issues have received tremendous attention in the planning circle, intellectual discussion and forums at national and global platforms. However, the existing lacuna in the formulation and execution of the policies has not changed the grass-root situations to a great extent of women in rural Odisha. There has been multipronged approach to make women prominently visible in development scene of Odisha. However, in spite of involvement of Government, non-Government organization in women empowerment through income generation and skill development programs, the status of women is still is not satisfactory in Odisha. In the background of gigantic transformation, the core issue, which still remains unanswered. In the present context, an honest attempt is made to understand the significance of 'women', 'micro enterprise', 'decision-making power of women' and the empowerment process of the women as a whole. Therefore, this study is undertaken to analyze the structure, performance and impact of microenterprises on the rural women in Cuttack district, Odisha. The problems associated with empowerment need to be outlined, and to suggest the possibilities to remove major obstacles obstructing the empowerment of rural Odisha women.

\section{Objectives}

The followings are the specific objectives of this study:

a. To study the present status of rural Odisha women participating in microenterprises.

b. Analyze the reasons for joining microenterprises.

c. Examine the activities undertaken by microenterprises programme.

d. Find the impact of microenterprises on rural Odisha women.

e.

\section{Hypothesis}

5.1 Participation of women in microenterprises empowers them and the more the participation, the more empowered they are.

5.2 Education status and smaller size of the family help in empowering the women.

\section{Research Methodology}

The study was conducted in two blocks namely Banki-II and Tigiria of Banki and Athagarha subdivision of Cuttack District. Stratified random sampling method was used to select the sample. Four numbers of Gram Panchayats were selected from each block was chosen randomly. Then, from each Gram Panchayat, 
sixteen numbers of Self Help Groups were selected randomly. The total number of SHGs is $128(16 \times 4 \times 2)$ taken as study unit. President, Secretary, and six members from each SHG i.e. $(128 \times 8)=1024$ in number of respondents were selected purposively. Then, a list of participants who had undergone skill development training for microenterprises by the government in different fields such as 'Chhatua, Agarbati, Candle, Masala, Badi, Pampad, Goatery, Shipery, Teracota, Applique, Rope-making, Spice-process, Weaving, Rice vending, Rice and Paddy business, Cattle rearing etc. was found with the help of industries officer. Total number of respondents found to be undergone training on the above said fields were 951. Equal proportions of respondents from this list were selected as sample for the present investigation. Hence, population was 951 in number and sample size was 474 in numbers of respondents were selected for the proposed study.

A structured interview schedule and guidelines was developed in keeping view the objectives of the study. Primary data were collected from questionnaire survey interviews and focus group discussions (FGDs) and key informant survey. Secondary data were collected from review of related documents, articles, and books. Survey with interview was done to collect the data from the respondents. In families, husbands, mothers and grown up sons and daughters were interviewed to understand the role of women and effect of the programme. Key information on the programme was collected from the CDPO, IPO, President of SHGS federation, programme Assistant of DRDA and local leaders. Participant women and community leaders participated in the FGDs in which almost same questions for the survey was used. The FGDs was intended for the women to speak freely and do self- assessment, and also for the community leaders to justify their programme outcomes and the roles of women. For measurement of empowerment i.e., decision-making capacity of women in personal and family matters, attempts were made through survey and interview to understand the situation of women prior to the programme intervention and the changes following the intervention.

The data collected from the participant women were validated. Analysis of data was done with the help of Excel programme (Analysis tool pack) i.e. cross tabulations, frequencies, and percentages. The microenterprise programme components were considered at the core inputs for measurement of empowerment, while family background of the women is used to see its effect on programme outcomes.

\section{Frame Work Of Empowerment}

The analytical framework for studying the empowerment of women has been implemented for the present study, illustrated in the schematic diagram Fig.1. The conceptual suppositions are skill development programmes aim to develop the income of women through participation in microenterprises. Skill development programmes are processes which lead to empowerment of women by providing them with income generating opportunities combining with its skills, access to resources and awareness among women. Here the dependent variable is empowerment, which depends on skill development programme for microenterprises with its basic components - skill, access to resources and awareness. The three basic components give opportunity to the women to earn income, which ultimately reduces the economic dependency of women. Reducing economic dependency can be a basis for empowerment. Women need to be engaged in a productive activity that gives them some financial autonomy. The increased level of income for women along with awareness improves the self-confidence and subsequently engages in decision making in personal and family affairs. Income in hand of a woman enables her confidence to put forward her opinion and share views in family decisions. In other words, women's economic contribution in a family makes way for her participation expected and accepted by the family members particularly by the family heads. The confidence and economic strength of women may motivate and enable her to participate in different social events and associations. Participation in microenterprises in this case is assumed to initiate a process for the women in which the women start developing their own self, their space in the family and society, which relates to empowerment ideologies. Development must be by people, not only for them. People must participate fully in the decisions and process that shape their lives (UN.1995), but at the same time promote a rather instrumentalist view of empowerment. Investing in women's capabilities and empowering them to exercise their choices is not only valuable in itself but is also the surest way to contribute to economic growth and overall development.

Neo-classical economic theory assumes that women have lower levels of education, training and on the job experience than men. Because families tend to allocate household resources to the education of male family members while expecting the women, as they grow up, to spend their time on housework and childcare for which training is not required. The theory further explains gender differences in employment in terms of differences in human capital where women are disadvantaged because of their family responsibilities, physical strength, education, training, hours of work. By this theory, we can understand that disadvantages of women lie in their lack of skill, awareness, education, and burden of responsibilities. Skill development programme is intended to provide them with skill, opportunity, and awareness to involve them in income generation activities, which is the hypothetical base of the proposed study. The aim to make women independent in making choices of her own and participate in family choices. 
Therefore in the proposed study the independent variables are as follows-

(a) Skill development programme / Income generating programmes with its three components- Access to Information, Access to Resources, Skill based Training. Here, Skill based training is designed to advance individual's general proficiency, especially in relation to their present or future occupations. Skill training prepares learners for jobs that are based in manual or practical activities, traditionally non academic and totally related to a specific trade or occupation. Access to resources refers to women's participation in saving and credit groups, saving mobilisation, loan provision, material support. Access to information refers to knowledge about the various agencies in their community.

(b) Family Background: Family background refers to size of the family, education of the family head and education of the women. Income refers to cash in hand of women, earned through the microenterprises business they are involved with.

(c) Income

The dependent variable is: 'more empowered, i.e. decision making capacity of women in personal and family affairs'.

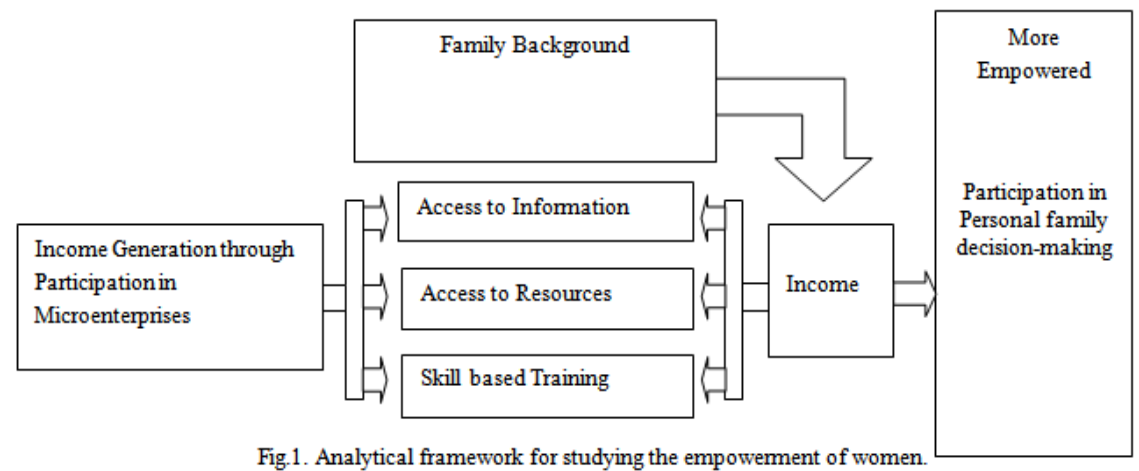

\section{Analysis Of Data And Interpretation Of The Results}

Statistical methods for data analysis were used to draw meaningful interpretation of the obtained results. Mean, standard deviation, coefficient of variations, and percentages of the collected data were calculated using the general statistical formula to determine the relationship between the observed variables.

\section{Motivation For Joining Micro-Enterprise Programme}

One Focus Group Discussion was organized involving direct and indirect beneficiaries of the incomegenerating programme intervention of members of women SHGs of Tigiria and Banki Block II in Cuttack district to get information through interaction about their interests to participate in microenterprise programme. The respondents reported about their reasons for joining microenterprise programme. To carry out this analysis, all the possible reasons were made known to the members of women. The distribution of respondents according to their reasons for joining microenterprise programme is shown in Fig.2. It is evident from the figure that most of the participants are self- motivated to join the training programme. Near about $42 \%$ of participating women join the programme, because, they felt that they need to do something for the family and they can earn if they get training. $34.39 \%$ women say that their family encouraged them to join the programme. Through interview, it is known that the family heads of the participating women are most farmers. Income from this farming is not enough to support their family expenses. The expenses are also on the rise. Therefore, the family heads want the female members to join such micro-enterprise programme. Women mention that they have found a new individuality through training.

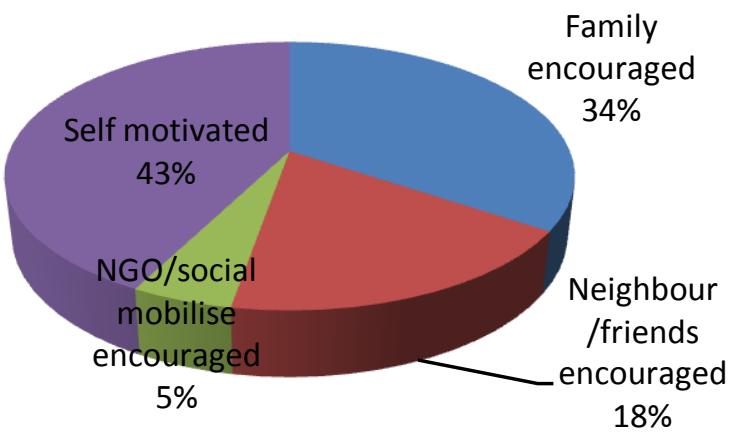

Fig.2. Distribution of respondents on various reasons for joining microenterprise programme. 


\section{Establishment Of Microenterprises}

Different Agencies like DRDA, MISSION SAKTI, ORMAS, SIDAC, NABARD, DIC, KVIC, and TRIPTI AND JANASADHANA are working for the promotion of microeneterpirse programme in the selected area. It is providing training to the women SHGS on Badi, Pampada, Spices, Agarbati, Pickles, Invitation, and Greeting Cards; Readymade garments making, handicrafts items, stone carving, Appliqué, Terracotta, Wooden toys, and several other items for establishing their own enterprises. After giving training, these organisations take care for arrangement of finance for SHGs for the purchase of raw materials and equipments for production of goods through bank linkages and microfinance. The SHGs utilize the money in the production of Badi, Pampad, Chhatua, Spices, Agarbati, Pickles, invitation and greeting cards, readymade garments, handicraft items, handloom items and several items. In order to enhance the knowledge of women SHGs about production and marketing these training organisations makes arrangement various exposure visit for trainees of food processing training programme to food processing unit like OMFED. Similarly, the visit to Ready Made Garments Unit, Spices unit, Carpet units, Handlooms and Handicrafts unit etc. are also arranged by these organisations. They also guide the SHGs to participate in various mela, exhibition both inside and outside of the state organized by Government and Non- Govt. Agencies for sale of their products. The respondents reported about their participation in different activities organized by microenterprise training programme. The distribution of respondents on the basis their interests for production of several items are given in Table 1.

Table 1: Distribution of respondents on their interest in several productions.

\begin{tabular}{|l|l|l|l|}
\hline Sl.No. & Item Production & Frequency (f) & Percentages (\%) \\
\hline 1. & Dairy, Goatery, Shepery & 108 & 22.36 \\
\hline 2. & Chhatua & 139 & 28.48 \\
\hline 3. & Agarbati,Candel, washing powder & 62 & 13.08 \\
\hline 4. & Masala (spice-process) & 33 & 6.33 \\
\hline 5. & Badi, Pampad,muruku,pickle making & 7.17 \\
\hline 6. & Bamboo work & 36 & 4.43 \\
\hline 7. & Teracoata & 20 & 3.59 \\
\hline 8. & Appliqué & 17 & 3.38 \\
\hline 9. & Rope-making, & 16 & 2.32 \\
\hline 10. & Weaving & 11 & 3.38 \\
\hline 11. & Rice vending & 16 & 2.53 \\
\hline 12. & Rice and Paddy business & 12 & 2.95 \\
\hline
\end{tabular}

The above results reflect that most of the rural Odisha women were engaged in 'Chhatua' item production for establishing their own enterprises. 'Chhatua' is mixture powder of wheat, groundnut, bengal-gram and sugar. Maximum women engaged in this activity to establish their own enterprise because there is no risk of marketing their products and purchasing of raw materials.

It is a fact that obtaining skill and utilizing it for earning income through establishing microenterprises are two different things. Once the women get training, they can use it as daily skill worker for other organizations or can use it occasionally at home and may establish self- business. It is generally agreed that having skill alone is not enough to start business. They need capital too. A study has been undertaken to know about the participating rural women what they did after the training and how they started their business or work. The distributions of respondents about their occupation before training and also after their training utilization training are given in Table 2.

Table 2: Distribution of respondents according to their training utilization.

\begin{tabular}{|l|l|l|l|l|l|l|}
\hline Sl.No & Occupation before training & $\begin{array}{c}\text { Frequency } \\
\text { (f) }\end{array}$ & $\%$ & Occupation after training & $\begin{array}{l}\text { Frequency } \\
\text { (f) }\end{array}$ & $\%$ \\
\hline 1 & Only household work & 374 & 78.90 & Only household work & 80 & 16.87 \\
\hline 2 & Working for earning & 100 & 21.90 & Start business on their own & 24 & 5.03 \\
\hline 3 & & & & Join other organisation & 71 & 14.98 \\
\hline 4 & & & & Working in related fields & 299 & 68.08 \\
\hline
\end{tabular}

The above results depict that $78 \%$ of the participants were just homemakers or doing just household jobs before they joined this programme. About only $21 \%$, women were engaged in little earning side by side with their household works. They were involved in weaving of sari, gamuchha, dyeing threads etc., as it is their traditional work. After getting training, 5.03\% women could start their business. They took loan from their groups, got support from their husband, grown up sons, daughters and with the help of training organizations in which they are involved. They started business on stitching of blouse and petticoats, making of badi, pampad, fried Bengal gram dal , Agarbati, phenyl, etc. Near about 16\% did not continue work relating to the training and join in other work or business after training for earning income. Maximum respondents (68\%) are working in related fields. Most of the women could not manage to open their own business or enterprise. The training gave those skills, 
information, and business management orientation. However, they could not initiate business on their own because they lack sufficient fund, enough motivation, and self-confidence.

A study has been undertaken to know about the participating rural women before as well as after training through microenterprises programmes. The distribution of respondents according to their income before and after training for microenterprises is listed in Table 3.

Table 3: Distribution of respondents according to their income before and after training for microenterprises

\begin{tabular}{|l|l|l|l|l|l|l|}
\hline Sl. No & $\begin{array}{l}\text { Income earning } \\
\text { (before training) }\end{array}$ & Frequency (f) & $\%$ & $\begin{array}{l}\text { Income earning (after } \\
\text { training) }\end{array}$ & Frequency (f) & $\%$ \\
\hline 1 & Not earning & 220 & 46.41 & Not earning & 90 & 18.99 \\
\hline 2 & Up to Rs.1500/- & 156 & 32.91 & Up to Rs. 1500/- & 222 & 46.84 \\
\hline 3 & Rs.1500-3000/- & 32 & 6.75 & Rs. 1500-3000/- & 157 & 32.12 \\
\hline 4 & Rs.3000-5000 & 0 & 0 & Rs.3000-5000/- & 71 & 14.98 \\
\hline
\end{tabular}

It is found that after getting the training on different trades, most of the rural Odisha women were engaged in work related to their skill. Near about $46 \%$ respondents did not earn anything before joining the training. However, after training it is found that near about $81 \%$ of the respondents earn through microenterprises. The involvement of women in training for micro enterprises has added an income up to Rs.1500/- and Rs.1500$3000 /-$ to $32 \%$ of the respondents. The respondents of about $14 \%$ earned up to Rs.3000-5000/-. Since some did not work or involve in micro-enterprises, 18 percent of the respondents have no increase in income at all.

\section{EMPOWERMENT OF WOMEN THROUGH MICROENTERPRISES}

Women became a member of Self Help Group in the beginning stage. Then, she involved herself in different credit and saving activities. Earlier it is found that the group members regarding the credit of the group took maximum decision. Respondent's husband took decision regarding the utilization of money always. In the present investigation, decision- making capacity of the respondents related to personal, family matters and savings studied before and after the training for microenterprises. Because, decision-making capacity is considered as an indicator of women empowerment in the present investigation and decision regarding savings of income is considered as capacity building.

Fig. 3 reflects the overall participation in decision-making of respondents in both family and personal matters. Before training, Twenty percent of respondents only always participate in decision-making and near about $38 \%$ of respondents never participate. However, after training, it is found that $41 \%$ of the respondents always participate in decision-making. It can be concluded that training was effective in bringing the change in decision-making capacity.

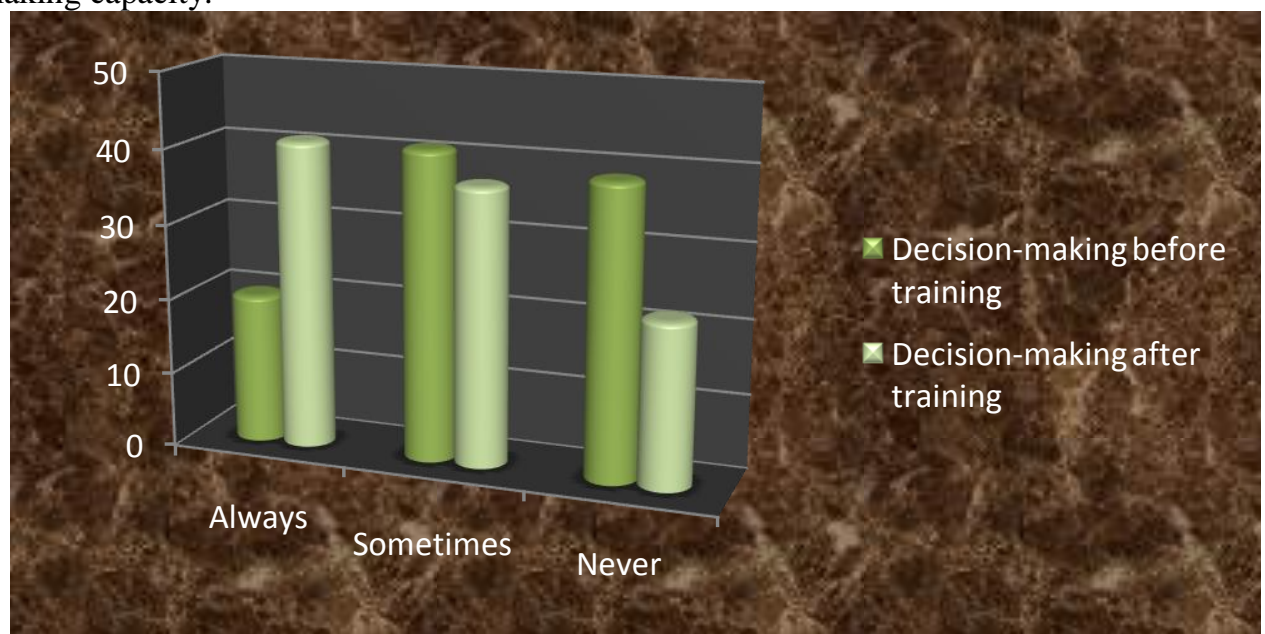

Fig.3. Overall decision-making capacity of rural Odisha women before and after training for microenterprises.

The decision- making capacity of the respondents related to personal and family matters are also studied before and after the training for microenterprises. The distribution of respondents according to their personal and family matters decisions are depicted in Table 4. 
Table 4: Distribution of respondents according to their personal and family matter decisions

\begin{tabular}{|l|l|l|l|l|l|l|l|l|}
\hline \multirow{3}{*}{ participation } & \multicolumn{4}{|l|}{ Decision-making before training } & \multicolumn{4}{l|}{ Decision-making after training } \\
\cline { 2 - 10 } & Personal matters & \multicolumn{2}{|l|}{ Family matters } & \multicolumn{2}{l|}{ Personal matters } & \multicolumn{2}{l|}{ Family matters } \\
\cline { 2 - 10 } & $\mathrm{f}$ & $\%$ & $\mathrm{f}$ & $\%$ & $\mathrm{f}$ & $\%$ & $\mathrm{f}$ & $\%$ \\
\hline Always & 56 & 11.81 & 39 & 8.23 & 112 & 23.63 & 83 & 17.51 \\
\hline mostly & 130 & 27.43 & 65 & 13.71 & 130 & 27.43 & 45 & 9.49 \\
\hline Never & 100 & 21.10 & 84 & 17.72 & 85 & 17.93 & 19 & 4.01 \\
\hline
\end{tabular}

It is evident from Table 4 that before participation in training programme for micro enterprises, $11.81 \%$ of the respondents always took decisions in buying personal items such as toiletries, personal clothing, ornaments, and some fancy items etc., visiting places, visiting market places or institutions, arranging recreational facilities and meeting with people. $21 \%$ of them never took decisions regarding their personal items, which shows their low participation in decision making. After women took part in training programme, $23 \%$ respondents found to take decision always on personal matters. Involvement of women in microenterprise training programme enhances their decision- making capacity on personal matters. Before involvement in training programme, only $8 \%$ respondents always took decision on family matters like child education, child's marriage making big and small purchases etc. However, after training $17 \%$ of respondents participated in family matters decisions. While interviewing the respondents, it was observed that the outside work of the family are carried out by the family members and even when the women go outside, family members escort them. The involvement of women in micro enterprise programme is usually linked with the different groups and institutions for their works and orders. Though, the changes in visiting markets and institutions is comparatively lower than other aspects still there was a wave of change in visiting market/other institutions to keep network for their business and orders, to buy goods for their enterprise, and to participate in exhibition for selling their products in the fair/mela at the village or cities.

In most of the village, male heads of the families are involved in agriculture farming and small business in the nearby market places. When they provide money alone to meet all family expenses, it becomes a burden on them, in meeting partial and small demands of the family expenses. Due to the involvement of women in microenterprise programme, they could earn something and it lessens the burden of head of the family to some extent. Besides that help, they also contribute more and more in maintaining the relationships by buying gifts for family members, treatment of the family guests, buying of new work simplification gadgets for household works, new dress for their husbands, sons and daughters. When the women do not have income, they have to ask consult the family heads about what they want to buy and why they need money. On the other hand, income-earning opportunities give women certain level of freedom of choices to buy their personal items, recreational items, and decisions regarding their business.

It is fact that when the women engage in income generation programme and start contributing to the family expenses, the women start enjoying respect of the family. This change implies that the status and respect of the women in their family are raised. Since they share more family responsibility, they command relationship of trust in families and their family members appreciate their work and feel proud for them.

\section{Problems And Suggestions}

The Self Help Groups (SHGs), through microenterprise programmes, is recognized as an important mechanism for empowering women. However, rural Odisha women have many restrictions and social taboos, they are not supported much by their family members to participate in microenterprise programme. The organizational constraints drive back the involvement of rural Odisha women in microenterprise training programme. The information regarding problems faced by rural women for participating in microenterprise programme is illustrated in Table 5. From the table 5, it is found that the empowerment of women is affected by the organizational constraints such as inadequate space, inadequate physical facilities, inefficient members to carry out the activities successfully, lack of co operation among members, lack of conveyance facilities, inadequate profit, decision made at higher level etc. 
Table 5: Information regarding problems faced by rural women for participating in microenterprise programme

\begin{tabular}{|c|c|c|c|c|c|c|c|}
\hline \multirow{2}{*}{$\begin{array}{l}\text { Sl. } \\
\mathrm{N} \\
\mathrm{o}\end{array}$} & \multirow[t]{2}{*}{ Organizational Constraints } & \multicolumn{2}{|c|}{ Major } & \multicolumn{2}{|c|}{ Minor } & \multicolumn{2}{|c|}{ Nil } \\
\hline & & $\mathrm{f}$ & $\%$ & $\mathrm{f}$ & $\%$ & $\mathrm{f}$ & $\%$ \\
\hline 1. & Inadequate space & 69 & 14.56 & 19 & 4.01 & 3 & 0.63 \\
\hline 2. & Inadequate physical facilities for marketing & 38 & 8.02 & 31 & 6.54 & 3 & 0.63 \\
\hline 3. & Inefficient members to carry out the activities successfully & 38 & 8.02 & 3 & 0.63 & 3 & 0.63 \\
\hline 4. & Lack of co operation among members & 116 & 24.47 & 28 & 5.91 & 3 & 0.63 \\
\hline 5. & Lack of conveyance facilities & 41 & 8.65 & 15 & 3.16 & 3 & 0.63 \\
\hline 6. & Inadequate profit & 107 & 22.57 & 22 & 4.64 & 3 & 0.63 \\
\hline 7. & Decision made at higher level & 69 & 14.56 & 12 & 2.53 & 3 & 0.63 \\
\hline 8. & Any other(Irregular cash received) & 6 & 1.27 & 0 & 0.00 & 3 & 0.63 \\
\hline
\end{tabular}

Suggestions:

The above problems can be solved by taking into account followings; with increasing educational opportunity among women, giving financial assistance, market facilities, developing of self employment programs, training through microenterprises programmes, subsidies, new schemes and organizing workshops, conducting research programme etc.

\section{CONCLUDING REMARKS}

The study shows that the microenterprise programme is as an important mechanism for empowering rural Odisha women. Briefly, it can be concluded that despite of few weaknesses, involvement of women in microenterprise training demonstrated a number of positive attributes in terms of operational simplicities, better accessibilities, wider outreaches, emphasis on women empowerment and availability of a wide range of credit and non- credit services. It helps in solving the problems like unemployment and poverty in India. The changes that have occurred between 'before' and 'after' stages of the microenterprise training are encouraging. A successful intervention for empowering women necessitates several elements- an important one is imparting of new skills: the consequence of women assuming new roles is also support through training for enabling them to perform these roles. Women should recognize clearly how society structures their perceptions. The training programme must promote critical analysis in women and encourage them to think independently and challenge unequal gender relations and exploitations. The women should think of occupation mobility to improve their incomes. The rural Odisha women need further exposure in the social front.

\section{References}

[1] Dhakal, N.H. (1999) " Expansion of Microfinance Services: the development of community basedsavings and credit Coperatives in nepal,' in Agriculture Credit, ,vol.31,July.

[2] Ab.Aziz, Y. Perumal, S. Feizreniah, P. (2005) Principles of Enterpreneurship. Petaling Jaya: Prentice Hall.

[3] Ogber O. John (2009) "Mythicizing and Reification in Enterpreneurial Discourse: Ideology- Critique of Entrepreneurial Studies" Journal of Management Studies 37 : 5 0022-2380 Published by Blackwell Publisher Ltd.

[4] Brunei, A., Gheradi, S. \& Paggio, B. (2004) . Doing Entrepreneurship : an Ethonographic account of Inert wined practices. Ge nder, work and Organisation, 11(4), 406-429

[5] Cole A. H (1959) Business Enterprise in Social setting; Harvard university Press, Cambridge.

[6] Schumpeter, J.A. 1939: Business Cycles, 2 vols. New York: McGraw-Hill

[7] Hisrich, R.D. and Peters, M.P. (1998). Entrepreneurship (4th. ed.). Boston: Irwin/McGraw-Hill

[8] Dillinger, B. (1995) Decentralization, Politics and Public Services. In: Estache, A. (ed.); Decentralising infrastructure: advantages and Limitations. The world bank discussion paper, Washington; D.C.

[9] Knight, F.H. (1921) “ Risk, Uncertainity and Profit ; Boston.MA : Houghton Miffin

[10] Cole, P.M. (2000). Understanding Family Business Relationship: Preserving the Family in the Business. The Family Journal: Counselling and Therapy for Couples and Families, 8(4), 351-359.

[11] Gibs, J. (1972), “ Issues in Defining Deviant Behaviour” in Theoretical perspective on Deviance, edited by Scott, R. A \& Dougles, J.D. Newwork, Basic Books Kantor, Paula (2002) Entrepreneurship: Theory and Practice/ Summer,2002 